\title{
"The plants have axé": investigating the use of plants in Afro-Brazilian religions of Santa Catarina Island
}

\author{
Tiago Santos Pagnocca, Sofia Zank and Natalia Hanazaki
}

\begin{abstract}
Background: Cultural and religious practices of African origin have decisively influenced traditional health practices in the Americas since the African diaspora. Plants are core elements in the religions of African origin. Compared with other parts of Brazil where the Afro-Brazilian presence is widely recognized, in Southern Brazil, these cultural practices are often socially invisible. Yet, there are several terreiros of three Afro-Brazilian religions: Candomblé, Umbanda, and Ritual deAlmas e Angola. We hypothesize that the importance of plants in Afro-Brazilian religions is linked not only to spiritual and magical issues but also to the medicinal properties of these plants. We seek to answer the following questions: (a) Which plants are used in the terreiros and what are their indications for use?; (b) Are there plants that stand out culturally in these religious groups?; and (c) What is the importance of the adaptive maintenance and replacement process in the use of plants in these religions, considering the Neotropical and African plants?

Methods: We performed a census of the existing terreiros on the Island of Santa Catarina to collect information on the knowledge and use of plants. In all terreiros that consented to participate in the research, we collected data through semi-structured interviews, guided tours for plant collection, and participant observation. We identified the botanical species through expert consultations and botanical literature.

Results: We interviewed 27 spiritual leaders, who cited 93 plants belonging to 86 botanical species. We identified 14 categories of use, with emphasis on liturgical ritual use (59\%), general and unspecified diseases (32\%), and digestive diseases (27\%). In most liturgics uses, direct contact between plant and patient occurs, as in the case of bathing and the cleansing use of smoke. Sixteen plants were cited in all terreiros, configuring a set of species that can be considered as culturally important plants for these religious groups.

Conclusions: These groups have extensive knowledge about a highly consensual set of therapeutic plants that should be further investigated pharmacologically to understand the effect of their external use. Also, we emphasize the importance of recognizing and valuing this ancestral Afro-Brazilian knowledge and learning also from these people about their broader vision of health which also adds more spirituality in health care.
\end{abstract}

Keywords: Ethnobotany, Medicinal plants, Candomblé, Umbanda, Ritual de Almas e Angola

\footnotetext{
* Correspondence: hanazaki@gmail.com

Laboratory of Human Ecology and Ethnobotany (ECOHE), Department of Ecology and Zoology, Federal University of Santa Catarina (UFSC), Campus Universitário Reitor João David Ferreira Lima, s/n, Florianópolis, SC 88040-900, Brazil
} 


\section{Introduction}

The African diaspora, a sociocultural and historical phenomenon, characterized by the forced immigration of the African population to countries that adopted slave labor, had a decisive influence on traditional health practices on the American continent. In the process, knowledge linked to health and the religious beliefs and traditions of African peoples has been combined with the knowledge of indigenous and European peoples who already inhabited this continent $[1,2]$. The relationships between African descendants and plants are addressed in various ethnobotanical studies related to: (a) the cultural contributions from medicinal and ritualistic practices [1-10]; (b) the exchange of plant species between the American and African continents and how these species became part of the landscape and local culture $[5,11-13]$; and (c) the influence of plant knowledge on the identity of Afro-Brazilian religions [4, 14, 15].

Africans have been present in Brazil since the early days of colonization in the sixteenth century. During this period, it is estimated that about 4.9 million people were brought as slaves to the Brazilian territory [16]. They were taken from various African regions and belonged to different ethnic groups; such as the Bantu speaking people from Angola, Congo, and Mozambique [1, 17]; and groups of Sudanese, from West Africa, from territories currently called Nigeria, Benin (ex-Dahomey), and Togo $[18,19]$. In the process of adaptation to the new territory, slaves became familiar with local plants, learning and adapting their knowledge of medicinal and magical properties and remodeling their medicinalritualistic system [20]. In this context, Medeiros et al. [21] argued that immigration provides two main processes for adapting knowledge: (1) replacement to the new flora of the host country and (2) maintenance through use and acquisition of the original flora from migrants' home countries.

Plants are key elements in the Afro-Brazilian religions, in which health is understood in a comprehensive manner, considering physical and spiritual aspects [3, 22]. In addition to direct use as a medicinal resource, as a remedy to cure physical illnesses, plants are also used in a liturgical and ritualistic way, through bathing, smoke cleansing, and other uses, as already described in ethnopharmacological studies [23]. It is important to assume that medicinal plants are frequently used with a ritualistic component, and rituals do play a role in the wellbeing of individuals and their cultural identity [24].

Currently, there are several religions of African origin in Brazil, which have been recreated and adapted over the centuries [25], even in the face of prejudice and racism. In southern Brazil, black people and their cultural and religious practices still suffer from a process of social invisibility, as a result of both historical racial prejudice [26, 27], and of the historical immigration characteristics of southern Brazil that especially value the European migrant identity. This is the first study to use an ethnobotany approach to address the plant uses in Afro-Brazilian religions in this region. In this context, we emphasize the importance of this research, aimed at registering and valuing the knowledge and practices of Afro-Brazilians, in order to strengthen the black identity and the social recognition of these groups in South Brazil.

On the island of Santa Catarina, in southern Brazil, three Afro-Brazilian religions are practiced: Candomblé, Umbanda, and Ritual de Almas e Angola (ritual of Souls and Angola); presenting a promising context for studies on their relationship with plants in their religious contexts. We hypothesize that the importance of plants in Afro-Brazilian religions is linked not only to spiritual and magical issues but also to the medicinal properties of these plants. In this way, we investigate the use of plants in these Afro-Brazilian religions, seeking to understand their importance in relation to their cultural, magical, and medicinal properties. We seek to answer the following questions: (a) Which plants are used in the terreiros and what are their indications for use including liturgical and physical illnesses' spheres?; (b) Are there plants that stand out culturally in these religious groups?; (c) What is the importance of the adaptive maintenance and replacement process in the use of plants in these religions, considering the Neotropical and African plants used for liturgic or physical illnesses?

\section{The religions of African origin in Brazil}

The ritualistic and religious activities of Afro-Brazilians occurred underground for many years, and gradually evolved into more organized gatherings. These ritual practices were called: calundú [28], drumming; and batuquejê, typified by collective dances, songs, percussion music, the invocation of spirits, possession sessions, divination, and magic rituals. These "societies," formed during the 17th and 18th centuries, are considered the antecedents of the candomble of the 19th century [20, 28]. In order to unite and strengthen themselves, slaves began forming the "saint families" (famílias de santo), composed of slaves from the same nation of origin. This led to the first terreiros, where Africans and their descendants gathered and established links based on ties of religious kinship [29]. The terreiros are the physical spaces where the religious ceremonies and their ritualistic activities take place, such as offerings, sharing the stories and fables of the saints, initiations, and where the conviviality of the familia de santo occurs.

Candomble emerged as a result of the maturing of the calundús, which began to gather groups of blacks in an organized manner and thus solidified and gradually 
developed a religious structure. In principle, rituals were restricted to domestic spaces and took place periodically, but with the abolition of slavery in 1888 and the proclamation of the Republic, they began to establish themselves as organized congregations in extra-domestic spaces. This started an Afro-Brazilian religious community that later consolidated as the Candomble religion $[1,28]$. One of the main symbolic elements within Candomble is the worship of Orixás (deities associated with the elements of nature). There are specific offerings for each Orixá and selected plants that are used in initiation rituals, baths, and other "obligations" [17]. In Candomblé, the Orixá known as the deity of the leaves is Ossaim, the owner of the forests and holder of all the wisdom and knowledge of the vegetable kingdom [17]. According to the African legends, Ossaim lives in the woods, where he learned all the secrets of the magic of the herbs.

Umbanda is a genuinely Brazilian religion, structured under the influence of the Iberian, Amerindian, and African cultures. According to Saraceni [30], Umbanda emerged as a branch of Candomblé around the mid-19th century, and by the beginning of the 20th century was so powerful that it had spread throughout Brazil [31, 32]. It is a Spiritist religion, strongly influenced by Kardecism (created in France by Allan Kardec and adopted in Brazil since the middle of the last century [30]).

In the 1940s, thirty years after its emergence, there were numerous branches of Umbanda, combining different ritual practices. During this period, the Umbanda de Almas e Angola was added to this ritualistic plurality, mixing Umbanda concepts with Candomblé practices. The Ritual de Almas e Angola practiced in Santa Catarina can be defined as a branch of Umbanda, but with particularities that bring it very close to Candomblé [33].

One of the basic foundations of these three AfroBrazilian religions is the use of plants in their liturgical rituals since they are carriers of axé, a primordial element for the accomplishment of ritual and religious works [34]. In these three ritual practices, plants are understood as essential parts of the healing practices. It is believed that plants can influence the spiritual plane and energetic layers that make up the aura of living beings, through an exchange of energetic fields. They can neutralize certain energies and enhance others, having a balancing effect.

\section{Methods}

\section{Study area}

The Island of Santa Catarina is located in the Southern region of Brazil, in the State of Santa Catarina. It is 54 $\mathrm{km}$ long, $18 \mathrm{~km}$ wide and has a territorial area of 424.40 $\mathrm{km}^{2}$, of which approximately $29 \mathrm{~km}^{2}$ are rivers and lagoons, with a great diversity of vegetation, hydrography, topography, and geology [35]. The island has two main vegetation formations in different successional stages: dense rainforest and coastal vegetation, which includes mangroves and restingas (sand dune vegetation) [36]. The island harbors the major part of the city of Florianópolis, the capital of the State of Santa Catarina. The population is estimated at 477,798 inhabitants, comprising approximately $14 \%$ blacks and $86 \%$ non-blacks [37].

At the time of European colonization of the island (mid-17th century), the area was inhabited by Amerindians from the Tupi-Guarani group, known as Carijós, whose subsistence was based on agriculture, fishing, and collecting mollusks [38]. The Portuguese colonization recognized the island as a strategic port for expeditions to the South Atlantic, with a strategic role in the defense of Brazil's southern limits [39]. From the mid-18th century, immigrants from Azores, Madeira, and continental Portugal settled on the Santa Catarina coast, expanding agriculture and fishing practices [40, 41].

African slaves were present on the Island since 1738, where they were forced to work on fortresses construction and whaling [42]. After the arrival of the Azorean immigrants, the number of African slaves also increased to work in the plantations, mills, and performing domestic services. Slaves always played roles that helped to build the city's economic and social history [43]. The arrival of black people on the Santa Catarina coast was more intense between 1789 and 1799, with the arrival of slaves coming from Pernambuco and Rio de Janeiro. African slaves and their descendants made up about $23.5 \%$ of the population of Santa Catarina from 1803 to 1857 [42].

In 1947, on the mainland area of Florianópolis, Malvina Ayroso de Barros, or Mother Malvina, founded the first terreiro of Umbanda, responsible for opening the way for the emergence of other rituals, such as Ritual de Almas e Angola in 1951, and the Candomblé that emerged in the region in the mid-1970s [44].

\section{Data collection and analysis}

We conducted a survey of the existing terreiros on the Island of Santa Catarina, identified through the website of the Union of Black Culture of Santa Catarina [45], which provides contact with the terreiros of AfroBrazilian religions registered in the region. This was complemented by online searches, resulting in a list of 40 terreiros. From the terreiros contacted, we used the snowball technique [46], in which the collaborators indicated other possible participants to be interviewed, each having the same characteristics (spiritual leaders of Candomblé, Umbanda, or Ritual de Almas e Angola, on the Island of Santa Catarina), thus covering as many people as possible fitting the research criteria.

We collected the ethnobotanical information through semi-structured interviews, between December 2015 and November 2016, related to the use of plants in the 
terreiros. We asked if plants were used as a healing (medicinal) resource, and if so, which plants and how were they used, as well as the socioeconomic information of the interviewees. Before data collection, we performed a pilot study in two terreiros outside the study area to adjust the methods and the interview protocol. The interviewees' participation was conditional to a prior informed consent agreement.

We also collected information through participant observation and guided tours [47]. We used participant observation [46] to gain a deeper understanding of the religious context associated with the use of plants. The guided tours were carried out in the backyards of the terreiro properties and in forest areas located nearby the terreiros, with the purpose of collecting the plants for botanical identification. We collected botanical material and identified the plants following standard botanical collection procedures [48], and in accordance with the Biodiversity Information and Authorization System SISBIO (Registration No: 49909 -1). We identified the botanical species using specific identification textbooks and expert consultations. The collected materials deposited in the Herbarium FLOR of the Federal University of Santa Catarina, and the Herbarium of the Agrotechnical School of Manaus (EAFM), of the Federal Institute of Education, Science, and Technology of Amazonas, under deposit numbers FLOR 60838 to 60857, EAFM 16715 to 16717, and EAFM 16744 to 16751. Plant names were checked with the plant list [49].

Some of the plant species cited in the interviews were not collected because the interviewee was unable to show them, often due to old age, or the absence or low abundance of specimens in backyards. Plants used in the rituals that were brought by the followers of the terreiro could not be collected. Whenever possible, we identified the non-collected plants based on the description of the plant made by the interviewee, the popular name, and with the aid of specific texts [50-53].

We analyzed the diseases through descriptive statistics. We categorized the diseases according to ICPC (International Classification of Primary Care) [54] as recommended by Weckerle et al. [55].

The similarity of knowledge was measured through an exploratory analysis of the cluster associated with the evaluation of the consistency of the clusters by SIMPROF analysis, due to the different number of terreiros between the religions. We used a matrix of presence and absence of the mentioned species. From this matrix, we calculated the Sorensen similarity matrix, with UPGMA clustering.

We considered those plant species with a higher percentage of citations in the three religions as culturally important plants. We performed a literature review of the ethnobotanical information of culturally important species by combining the term "ethnobotany" with "AfroBrazilian" or "Candomblé" or "Umbanda" or "Almas e Angola." We did not search for exhausting information of each species, but to show the existence of studies that show the use of these plants by other afro Brazilian groups.

We classified the plants concerning the place of origin according to the system suggested by Vavilov [56] based on eight centers of diversity or biogeographic regions: I-Chinese, II-Indian, III-Central Asian, IV-Near East, V-Mediterranean, VI-Ethiopian, VII-Mexican and Central American, VIII-South American. The classification was based on Prance and Nesbitt [57], Lorenzi and Matos [52], and complemented with Flora do Brasil 2020 [58].

To explore the adaptive process of maintenance and replacement in the use of plants [21], we analyzed the proportion of Neotropical and African components in relation to other places of origin, and in relation to liturgical and physical illness. The plant origins were grouped into three major groups: Neotropical (groups VII and VIII), African (VI), and Others (I to V). The differences between the plants of Neotropical and African origins in the context of liturgical or physical illness were compared through a chi-squared test. Only the plants mentioned exclusively for liturgical or physical illnesses (and not both uses) were incorporated into the analysis.

\section{Results}

\section{Description of the collaborators}

Among the 40 terreiros initially identified, 13 were excluded due to either: refusal to participate in the study, were not contactable, or were permanently closed. Twenty-seven Babalorixás and Yalorixás (Saint Mothers and Fathers, or spiritual leaders) were interviewed from Afro-Brazilian terreiros on the Island of Santa Catarina. Of those, 13 practiced the Ritual de Almas e Angola, 11 Umbanda, and 3 Candomblé. The group of 27 interviewees was composed of 9 men and 18 women, aged between 34 and 67 years (mean of 56.48 years, s.d. 8.77). Seventeen were retired and performed exclusively, the role of the spiritual leader, while ten affirmed that they worked in other activities besides performing the function of spiritual leader. Only two respondents did not reside in the same location as their terreiros, which were usually located behind their houses.

The studied terreiros were located in urban areas, with restricted space for the cultivation of plants. However, even within this limited space, we observed the cultivation of many useful plants as well as those collected from the wild, in nearby forests, where rituals are also performed. 


\section{Knowledge and use of plants}

We recorded 93 plants used in the terreiros, from which it was possible to identify 86 species belonging to 37 botanical families. The mean number of plants cited per respondent was 35.6 species (s.d. $=3.6)$. Of the cited species, $42 \%$ are exclusively for medicinal use and not linked to a liturgical use, $32 \%$ are indicated only for liturgical uses and $26 \%$ of the species are used in both contexts.

We identified 14 categories of uses (Fig. 1), with emphasis on liturgical use (59\% of the species), general and unspecified diseases (32\%), digestive $(27 \%)$, respiratory (15\%), urological (14\%) psychological (12\%), and endocrine, nutritional and metabolic diseases (10\%). We classified a plant as liturgical when the use was not directly related to a physical issue (e.g., cleansing and harmonizing baths, protection against the evil eye). However, we do understand that a liturgical use also has a medicinal and healing effect, and a medicinal use frequently involves some kind of ritual.

Among the species cited for use directly related to a physical issue, the most indicated forms of use were teas and infusions (54\%) and antiseptic gargles (7\%). Within the context of liturgical use, seven forms of use were identified: bathing, smoke cleansing, amaci, protection, offering, "making of saint" (or feitura de santo), and blessing. Amaci is a specific washing ritual. It occurs annually, in a day defined by each terreiro, and is a ritual of maintenance of the energies of already initiated people from the terreiro. In this ritual, several plants are mixed in a clay pot with water from the sea of waterfalls, and this water is used after a few days. The "making of saint" is an initiation ritual in which the person is kept recluse for a few days, and after that he/she is presented to his/her Orixá and to the plants guiding this entity, from which the bath is prepared. The most cited indications were for bathing, smoke cleansing, and amaci, with $35 \%, 29 \%$, and $15 \%$ respectively (Fig. 2 ).

We recorded two types of baths: first, the energy cleansing or flushing, which aims to remove the dense energies of the patient, and second, the baths of harmonization or sweetness that are used to bring prosperity or happiness. The baths are prepared through infusion and are then poured over the body, allowing it to dry naturally. Different plants are used for each type of bath. In flushing baths, for example, stronger plants such as arruda (Ruta graveolens), abre-caminho (Justicia gendarussa), and guiné (Petiveria alliacea) are used. Whereas in the harmonization baths sweeter plants, like alecrim (Rosmarinus officinalis), lavanda (Lavandula dentata), and menta (Mentha $x$ villosa) are used. Common baths can be indicated to initiated and noninitiated people, and usually the plant to be used is indicated by the priest, but not furnished to the user. Recommendations for plant collection are to collect the plants in the beginning on ending of the day (never at noon), and sometimes is also recommended to collect the plants during the full moon. Some priests recommend that women in their periods should not collect plants, to avoid the mixing of energies.

Smoke cleansing is also performed as a way to clean and harmonize people and spaces, through burning plants on charcoal. Many of the plants used in the cleansing baths are also used for smoke cleansing. Usually, the plants used for smoke cleansing are collected by one initiated person, who is also responsible for the drying process of the plants, and for the smoke cleansing itself. Smoke cleansing happens before the spiritual works, with the purpose to fill the gaps with the spiritual world and to better connect with spirits. The amaci is a ritual

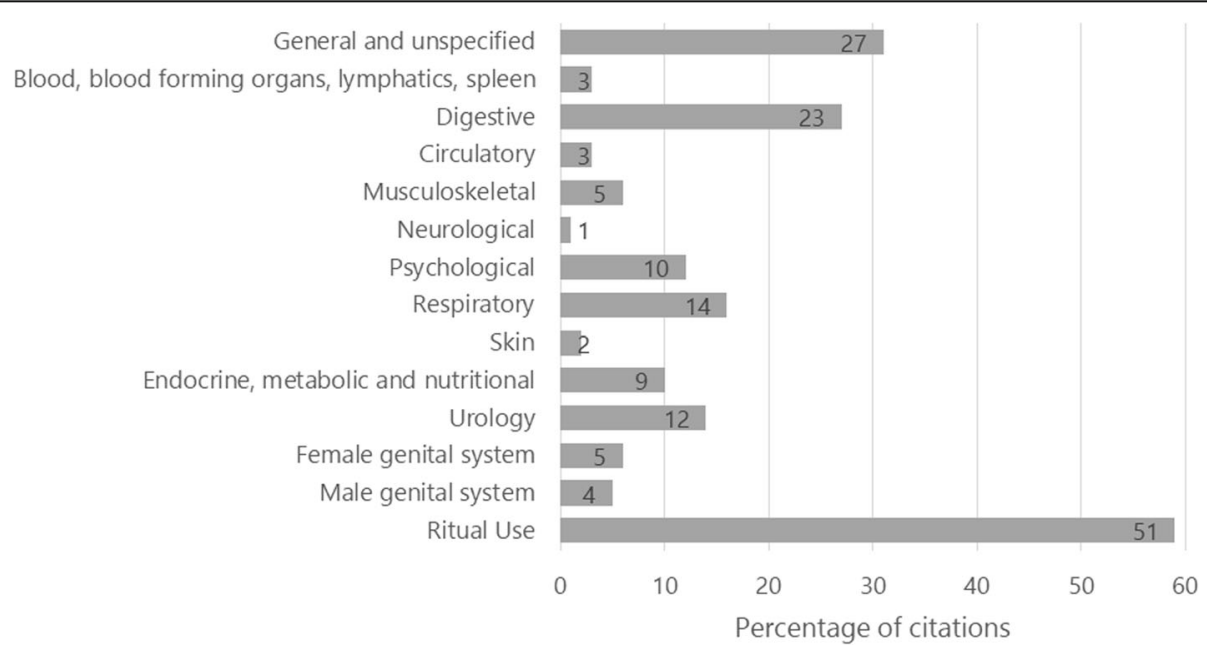

Fig. 1 Indication of use of the 86 plants cited by the interviewees from 27 terreiros in the Island of Santa Catarina, Brazil. Absolute values are indicated inside each bar 


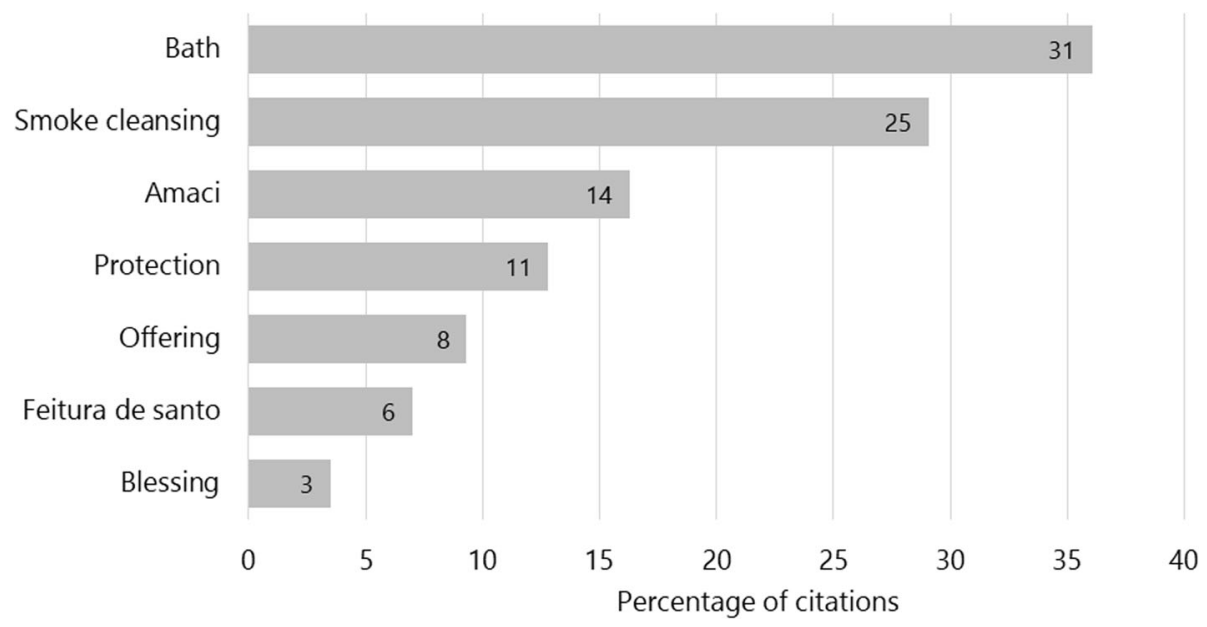

Fig. 2 Uses of the 50 liturgical plants cited by interviewees from 27 terreiros in the Island of Santa Catarina, Brazil. Absolute values are indicated inside each bar

of washing the head of the mediums, using plants specific to each Orixá, aiming to connect the medium and strengthen the bonds with the spiritual guides.

The plants used for protection are those that have the power to block the negative energies of other people and from the self, as well as from the disembodied spirits. They are usually grown in pots or on the ground near socialization spaces. The comigo-ninguém-pode (Dieffenbachia seguine) is an example of a plant used for protection. The offerings or ebó are ritual offerings or animal sacrifices (which are not frequent and usually are of chicken, and rarely of goats) offered to the deities or ancestors, in which plants are also used. They are performed in appreciation of blessings received or seeking to resolve problems. Pimenta-malagueta (Capsicum frutescens), Pimenta-dedo-de-moça (Capsicum baccatum), and Lirio-de-oxum (Hedychium coronarium) are examples of plants used in offerings.

Feitura de santo ("making of saint") is a term used for the ritual of initiation into the religion, in which the initiate happens to be officially a child of a saint (filho de santo) of the terreiro. The plants are placed for the initiate to lie on them, and in this way receive their vital energy (the axé). In the past, the initiated person had to lie on her/his plants during long time spans (up to 6 months), and frequently this required the person to move to the terreiro. Nowadays, this contact with the plant is done for 1 week or during one weekend. In the blessing, a branch of the plant is used, which the blesser holds in one hand and makes movements around the recipient with the other hand, being able to touch the recipient, or not. The blesser, however, is believed to be the spirit incorporated in the medium, and particularities of blessings vary between terreiros. Examples of plants used in blessings are common rue (Ruta graveolens), rosemary (Rosmarinus officinalis), and bellyache bush (Jatropha gossypiifolia).

The bath, the amaci, the smoke cleansing, and the feitura de santo are liturgical uses that have direct contact with the body. In this usage, the pharmacological principles of the plants may be acting. On the other hand, the plants used in offerings, and cultivated for protection, do not have direct contact with the physical body, and their use is associated with the magical and spiritual characteristics of these plants. The plants used in the blessings are considered to be of indirect use because there is little contact with the body of the individual being treated. Of the total number of plants mentioned, $93 \%$ are of direct use, including those used to cure specific physical issues (teas/infusions, gargles, syrups, among others) and the liturgical ritualistic ones (bathing, amaci, smoke cleansing, feitura de santo); $7 \%$ are plants of indirect use only (protection, offerings, and blessings).

The comparison between the plants used by the three religious groups showed that from the 86 plant species listed, 56 are used by all three groups, 20 are used only by Ritual de Almas e Angola and Umbanda, one species is used only by Candomblé and Umbanda, 2 species are exclusive to Ritual de Almas e Angola (Artemisia absinthium and Datura suaveolens), 1 exclusive to Candomblé (Polyscias guilfoylei), and 6 exclusive to Umbanda (Pyrostegia venusta, Foeniculum vulgare, Fragaria sp., Peperomia pellucida, Vernonia condensata, and Pereskia aculeata). Cluster analysis and SIMPROF showed no significant difference in knowledge about plants between groups, as they share a large number of species. There is a similarity of $89.41 \%$ between Almas e Angola and Umbanda; 70\% between Almas e Angola and Candomblé, and $67.85 \%$ between Candomblé and Umbanda groups. 
All respondents answered that they understood the plants as a basic and fundamental element for AfroBrazilian religions, and without them, it would not be possible to carry out the religious works since the plants are holders of the axé, the primordial energy accessed in rituals.

\section{Culturally important plants}

A set of sixteen plants (19\% of all species identified) was cited by all the interviewees, demonstrating that although they are from different religious groups, much of the knowledge about the use of these plants is shared (Table 1). All the 16 shared species are used in the liturgical context, and seven of them are also used to heal issues related to specific physical symptoms. Two plants are only used as protection, without direct contact with the body: Dieffenbachia seguine and Sansevieria cylindrica. Dieffenbachia seguine is a toxic plant as are the two varieties of Sansevieria trifasciata, also used for protection, for rituals of bathing, amaci, and smoke cleansing.

All culturally important plants were recorded in other ethnobotanical studies with Afro-Brazilian groups (Table 1). R. officinalis, O. basilicum, R. graveolens, and $P$. alliacea are the plants with the largest number of records, demonstrating their wide use in the various AfroBrazilian regions and groups, as well as in different regions of Brazil.

Eight of these culturally important plants originate from the Old World (five from the Mediterranean region and three from India), which may reflect the ethnobotanical knowledge exchange and adaptation of ritualistic plants from contact between the African diaspora and European settlers. Besides, five of these plants originate in the Neotropical (South and Central America), which may indicate the exchange and integration of rituals and knowledge of local indigenous peoples. Only three of these plants, the species of the genus Sansevieria, originate from the African continent, whereas Sansevieria trifasciata is native to tropical West Africa from Nigeria east to the Congo and S. cylindrica is native from Angola.

\section{Neotropical and African components}

Most of the plants are from other regions than home (African) and host (Neotropical) migrants continents (Fig. 3). Among the plants of African origin (9 species), only one is associated exclusively with physical illnesses, 5 are exclusive to liturgical uses and 3 are used for both, showing some preference in maintaining the use of plants from the continent of origin for ritual and liturgical uses. Plants of other origins are used equally for ritualistic use as well as to treat physical problems. Among the plants of Neotropical origin, 17 are used exclusively to deal with physical issues, 9 exclusively for liturgical rituals, and 6 for both uses. For the plants of other origins, 15 are exclusively used to address physical illnesses, 14 for liturgical uses, and 16 for both. Chisquare comparison between plants of African and Neotropical origins for liturgical uses and body problems was not significant (chi-square with Yates correction = 2.9304, $p<0.05$ ). However, the proportion of Neotropical: African plants of 1.8 for ritualistic and 17 for body or physical illnesses, that means that for each $1.8 \mathrm{Neo}-$ tropical plant cited for liturgic use, 1 African plant is mentioned; but for every 17 plants for physical illness use of Neotropical origin, 1 African plant is cited. These results emphasize that the process of maintenance of African plants is stronger in the context of liturgical rituals than for specific physical issues. In the context of replacement, both Neotropical components and from other origins played an important role, since both were incorporated through exchange with other cultures in the ritualistic and physical contexts.

\section{Discussion}

The richness of plants registered in the Candomblé, Umbanda, and Almas e Angola religions on Santa Catarina Island reinforces the importance of plants in AfroBrazilian religions, in the conceptualization of health, and the religious and cultural identity of these groups. Plants are an essential element for these Afro-Brazilian religions because the plants are detainees of the primordial energy accessed in rituals-axé. Even with the terreiros being located in urban areas, where there are few spaces for the collection and cultivation of plants, these areas still maintain the use of a diversity of plants.

In general, the three religions presented a highly shared knowledge base (sharing 65\% of the species), which may reflect both the shared origin of these religions and a possible contemporary exchange of information between the interviewees. Umbanda and Ritual Almas e Angola presented a greater number of shared species, which may be related to the origin of Almas e Angola as a branch of Umbanda, but can also be influenced by the smaller sample size of Candomble terreiros (only 3 terreiros). The few species unique to each religion can reflect distinctive inner customs and traditions within groups, such as specific initiation practices, offerings, and obligations. However, we observed high variability in the specific practices of each terreiro. Although the spiritual beings play a very central role in these religions, it would be interesting if other studies investigated the process of transmission and adaptation of this knowledge, and cultural resistance in the Afro-Brazilian religions.

A highlight in this study is the existence of a group of sixteen plants that was shared by $100 \%$ of the interviewees. While much knowledge may be considered diffuse knowledge, which is, shared by many communities, 
Table 1 Plants cited by 27 interviewees from terreiros of Ritual de Almas e Angola (13 terreiros), Candomblé (3 terreiros), and Umbanda (11 terreiros) in Santa Catarina Island, Brazil

\begin{tabular}{|c|c|c|c|c|}
\hline Local name & $\begin{array}{l}\text { Voucher/collector } \\
\text { number }\end{array}$ & Uses & Origin & $\begin{array}{l}\text { Ethnobotany use Afro- } \\
\text { Brazilian groups }\end{array}$ \\
\hline
\end{tabular}

Abre-caminho or quebra-demanda (Justicia gendarussa Burm. f.)

FLOR60846

Araceae

Comigo-ninguém-pode (Dieffenbachia seguine (Jacq.) Schott.)

\section{Asparagaceae} de-lansã (Sansevieria trifasciata var. laurentii (De Wild.) N.E.Br, syn. S. trifasciata)

Espada-de-São-Jorge or Espada-deogum (Sansevieria trifasciata Prain)

Lança-de-Ogum (Sansevieria cylindrica Bojer ex Hook.)

\section{Lamiaceae}

Alecrim (Rosmarinus officinalis L.)

Alfazema (Lavandula angustifolia Mill.)

Boldo-de-Oxalá (Plectranthus barbatus Andrews)

FLOR 60855

Hortelã (Mentha $x$ villosa Huds.)

TP17

Lavanda (Lavandula dentata L.)

FLOR 60854

Manjericão (Ocimum basilicum L.)

FLOR 60841

\section{Phytolaccaceae}

Espada-de-Santa-Bárbara or Espada-
Energy cleaning (amaci, bath, smoke cleansing)

Evil eye (protection)

Energy cleaning (amaci, bath, smoke cleansing); protection;feitura de santo

Energy cleaning (amaci, bathing, smoke cleansing); protection;feitura de santo

Evil eye (protection)

Energy harmonization (amaci, bath, smoke cleansing); feitura de santo; blessing;depression, poor digestion, cardiovascular problems (tea)

Energy harmonization (bath, smoke cleansing);feitura de santo

Energy cleaning (amaci, smoke cleansing, bath), offering; bronchitis (syrup)

Energy harmonization (bath); soothing (tea)

Energy harmonization (bath, smoke cleansing)

Energy cleaning (smoke cleansing, bath); feitura de santo; offering;bronchitis (tea, syrup)
Candomblé and Umbanda [59]

VIII Candomblé and Umbanda [59-61], Maroons [6]

VI Umbanda Nagô [62], Candomblé and Umbanda [59, 63]

VI Umbanda Nagô [62], Candomblé [60, 64], Candomblé and Umbanda $[59,61,63]$, Maroons [6]

VI Umbanda Nagô [62], Candomblé and Umbanda [59]

V Candomblé Kétu Nàgó [65], Candombl é[64], Candomblé and Umbanda $[61,63]$, Umbanda $[66,67]$, African-based religions $[68,69]$, Afro-brazilian religions [3], Maroons [70-72]

V

Candomblé and Umbanda [61]

Afro-Brazilian religions [3], Candomblé [64], Maroons $[6,70,72]$

Umbanda Nagô [62], Candomblé and Umbanda $[61,63]$, Umbanda [66], Maroons [70, 72]

Umbanda [67]

Candomblé Kétu Nàgó [65], Candomblé and Umbanda [59], Umbanda [67], Africanbased religions [69], AfroBrazilian communities [73], Afro-Brazilian religions [3], Maroons $[6,70,71]$
FLOR60856

Guiné (Petiveria alliacea L.)

Energy cleaning (amaci, bath, smoke cleansing); protection

VIII

Candomblé $[2,74]$, Umbanda [66, 67], Africanbased religions [68, 69], Afro-brazilian religions [3], Maroons [75]

\section{Rutaceae}

Arruda (Ruta graveolens L.)
TP11
Energy cleansing (amaci, bath, smoke cleansing); blessing; protection; feitura de santo
R: Umbanda Nag ô[62], Candomblé [64, 74], Candomblé and Umbanda $[59,61,63]$, Umband a[66, 67], Afro-Brazilian religions [3], 
Table 1 Plants cited by 27 interviewees from terreiros of Ritual de Almas e Angola (13 terreiros), Candomblé (3 terreiros), and Umbanda (11 terreiros) in Santa Catarina Island, Brazil (Continued)

\begin{tabular}{|c|c|c|c|c|}
\hline Local name & $\begin{array}{l}\text { Voucher/collector } \\
\text { number }\end{array}$ & Uses & Origin & $\begin{array}{l}\text { Ethnobotany use Afro- } \\
\text { Brazilian groups }\end{array}$ \\
\hline & & & & Maroons $[6,70-72,75]$ \\
\hline \multicolumn{5}{|l|}{ Solanaceae } \\
\hline Fumo (Nicotiana tabacum L.) & - & Energy cleaning (smoking) & VIII & $\begin{array}{l}\text { Candomblé and } \\
\text { Umbanda [61, 63], } \\
\text { African-based } \\
\text { religions [69] }\end{array}$ \\
\hline $\begin{array}{l}\text { Pimenta- malagueta } \\
\text { (Capsicum frutescens L.) }\end{array}$ & TP16 & \multirow{2}{*}{$\begin{array}{l}\text { Offering; baths in specific } \\
\text { cases of protection; for lack } \\
\text { of energy, anti-inflammatory, } \\
\text { aphrodisiac, antiarthritic, } \\
\text { anticancer }\end{array}$} & VIII & $\begin{array}{l}\text { Umbanda Nagô [62], } \\
\text { Maroons [6] }\end{array}$ \\
\hline $\begin{array}{l}\text { Pimenta-dedo-de-moça } \\
\text { (Capsicum baccatum L.) }\end{array}$ & TP15 & & VIII & Umbanda Nagô [62] \\
\hline
\end{tabular}

Origins: II, Indian; V, Mediterranean; VI, Ethiopian; VII, Mexico and Central America; VIII, South American

it is rare in ethnobotanical studies for knowledge of a given set of plants to be shared by all or most of the respondents. This high degree of shared knowledge among interviewees may be reflecting a capacity for cultural resilience, and unity among these religious groups. A few studies on medicinal plants in groups of Afrodescendants, citing plants used by the collaborators, showed that the shared knowledge base (the same species mentioned by different interviewees) is usually lesser than $50 \%$ of the collaborators $[71,72]$, or with few species with a quota above $50 \%$ [76].

Also, these sixteen plant species shared by all terreiros must possess a cultural value in the formation of the local identity of these religious groups. The sixteen plants shared by all interviewees appear in other studies with AfroBrazilian groups, demonstrating its importance to AfroBrazilian identity, local health systems and religious rituals, independent of the Brazilian region [2, 3, 59-70, 74]. The

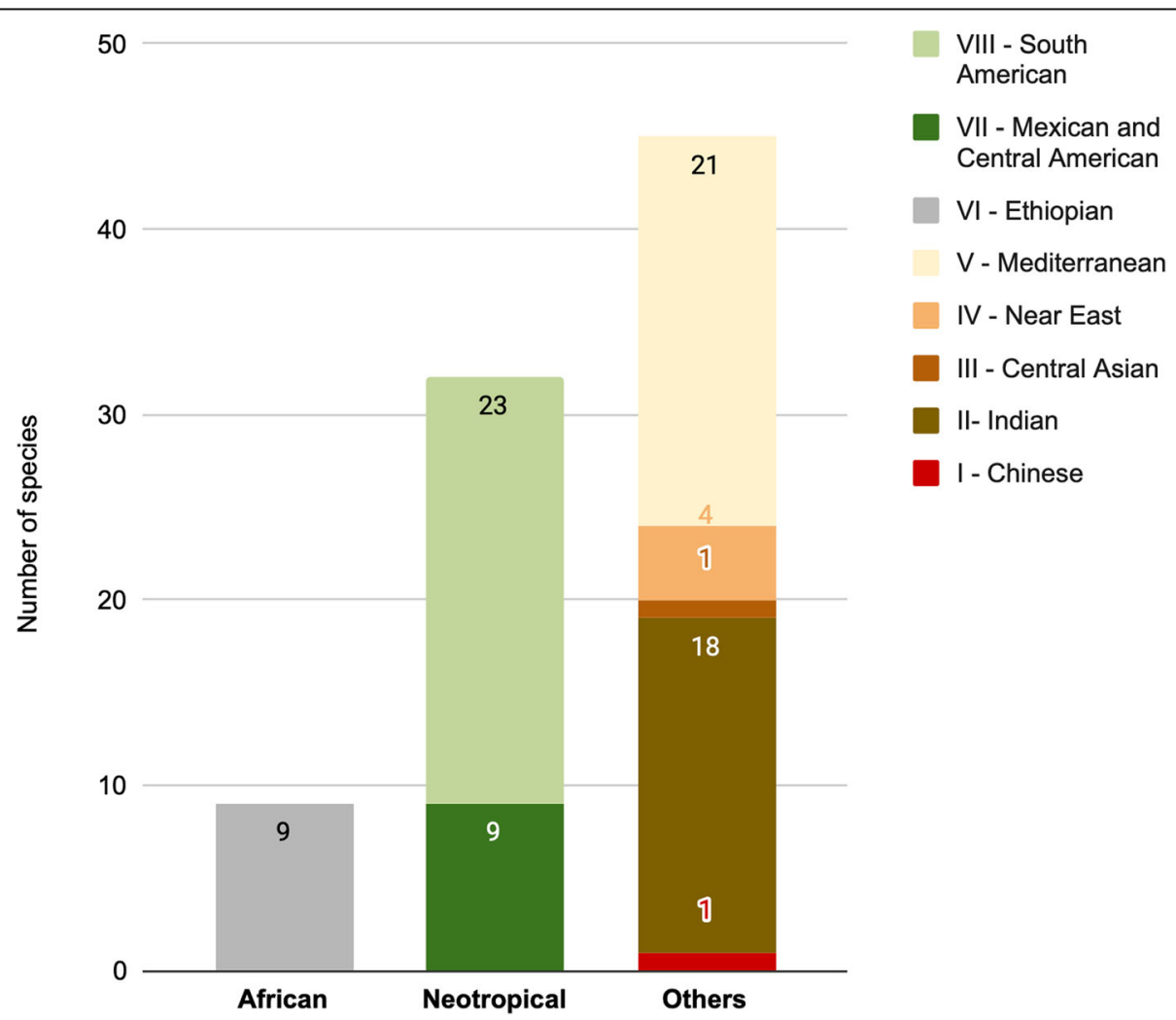

Fig. 3 Geographic origin of the 86 plants cited by interviewees from 27 terreiros in the Island of Santa Catarina, Brazil. Absolute values are indicated inside each bar 
cultural importance of some species is not restricted to Afro-Brazilian groups, since some plants are common in Brazilian pharmacopoeias, such as Rosmarinus officinalis, Plectranthus barbatus, and Ruta graveolens [52]. Some of them are also used in Afro-religious contexts in other places in South America, such as Suriname, and in African countries such as Gabon and Benin (e.g., species of the genera Justicia, Ocimum, and Capsicum [77, 78]. Thus, this consensual set of 16 plants may be one of the links that connect them to the common African ancestral origin within this Brazilian historical and social context.

Plants used to heal specific physical conditions are used in the terreiros mainly to treat simple health problems, such as digestive problems (e.g., stomach aches and nausea), and general and unspecified diseases (e.g., pain and inflammation in general), and this what was also registered in studies in the context of Afro Brazilian religions [3]; with Maroons [6] and with medicinal/ magic plants from a public market [79]. On the other hand, it is important to emphasize that these categories of use are not restricted to Afro-Brazilian groups, and were also observed in studies on the complementary use of medicinal plants and biomedicine [80], showing the preference of using plants to treat simpler health problems such as digestive, respiratory, and general pains. A fact that should be highlighted is the large number of species indicated for ritual use related to the magic-religious nature of the three groups, confirming other studies of plants of African-Brazilian rituals $[8,63,64,68]$.

Among the liturgic ritual use, those with direct contact with the body, such as bath, smoke cleansing, amaci and feitura de santo, stand out. Baths also had the highest indications for ritual use in similar studies by Carvalho et al. [61], Gomes et al. [63], and Pires et al. [64], as well as in studies in Suriname with African descendants [81] and African peoples of Benin and Gabon [23]. These forms of use highlight the maintenance and adaptation of imported cultural practices for African descendants throughout the diaspora process [2]. In addition, the amaci can also be considered as a specific form of bath, directed only to the "sons/daughters of saint" (filhos de santo), but in this work we treated them separately from the baths because this is how the Saint Mothers and Fathers referred to them.

Species used for bath, smoke cleansing, amaci, and feitura de santo were reported for similar purposes in other studies, such as the use for baths of Justicia gendarussa and Sansevieria spp. in Minas Gerais (Brazilian Southeast) [59], and Lavandula dentata in other parts of southern Brazil [65]. These and other species with ritualistic uses were investigated for pharmacological properties, such as J. gendarussa [82, 83], S. trifasciata [84, 85], L. angustifolia [86], L. dentata [87], $R$. graveolens [88]. However, except for Petiveria alliacea, none of the 16 plants had these properties investigated in the context of the ritualistic use. After simulating the route of administration of the site where the ritual is performed, Alves et al. [89] found no effect on locomotor activity or anxiety-like behavior of $P$. alliacea in laboratory animals, and called the attention to possible negative effects of such administration.

These ritualistic uses of direct contact with the body may indicate that the use of plants in rituals is based not only on the magical power of plants but also on the medicinal principles of these plants, as already evidenced by Quiroz et al. [23] and Garcia et al. [67]. Also, it is important to emphasize that the ritualistic use of indirect contact with the body (e.g., offerings and protection) does not indicate that they have no action on people's health. The health system associated with Afro-Brazilian religions, as well as traditional health practices, are based and justified within their culture of existence.

The high number of plants from other places like the Mediterranean and Asia Minor regions is related to the diversity of species that were introduced to Brazil by the colonizers that were subsequently incorporated by the Africans as a substitute for medical and ritualistic practices in the new continent [3]. In this way, the process of construction of the cultural identity of these AfroBrazilian religious groups involved the participation and contribution of many cultures, in a process of appropriation, import, and export of species [1, 2, 11]. The maintenance of a few species from the Ethiopian region (continent of origin), such as the Sansevieria plants, may seem contradictory because they are Afro-Brazilian religions, but this may be related to the difficulty that slaves had in bringing their plants on the slave ships, as discussed in the works of Voeks [9, 10] and Matory [90]. On the other hand, the maintenance of plants of African origin associated with liturgical use reinforces the importance of these religions in keeping their identity and of cultural strengthening of these groups. Also, the presence of Neotropical plants illustrated by species such as Dieffenbachia seguine, Petiveria alliacea, Nicotiana tabacum, and plants of the genus Capsicum may be a result of the exchange of ethnobotanical knowledge between indigenous people and people of African descend [9], leading to current Afro-Brazilian pharmacopoeias being numerically dominated by Neotropical or Mediterranean taxa. In addition, it is important to highlight that $P$. alliacea (a Neotropical plant) is employed in West Africa and Brazil for similar medicinal and magical purposes [91], demonstrating that the exchange of knowledge also influences the medicinal repertoire in the continent of origin of these groups.

All 16 culturally important species are used in liturgic rituals, and half of them are also used to treat physical issues. Toxic plants are mainly used for protection, and 
this may be related directly to the knowledge of the toxic effects of these plants held by traditional people. In the case of $D$. seguine, its magical use is believed to have been built from its use as a toxic plant to punish slaves [92].

The wide use of these plants by different AfroBrazilian groups may be an indicator that this use is not only due to the magical properties of the plant, as previously discussed, especially in the cases in which the mode of the application allows some contact of the person to be healed with the plant used. Also, these results highlight the importance of promoting phytochemical and pharmacological investigations into species of ritual use to understand the effect of their external application on the human body [23, 67].

As well as calling attention to the pharmacological potential of these species, we also highlight the importance of the ethical issues associated with ethnobotanical and pharmacological research. It is fundamental to value and respect the people who have for so long created, innovated, and transmitted such knowledge that benefits so many people, including in contemporary urban societies, benefiting from drugs derived from traditional knowledge. To achieve this, researchers must develop their research following the international guidelines of the Convention on Biological Diversity, as well as any specific national legislations and regulations, for the protection of this local knowledge and benefit-sharing. In this way, we collaborate to reduce the prejudice and invisibility experienced by groups of Afro-Brazilian religions in Brazil, and in other American countries.

As discussed by Quiroz et al. [23] and Reyes-García [93], the results of this study also make us reflect on our Western views on the ritualistic use of plants, which are often treated only as a matter of "belief and faith." This view stems from Western science's tendency to separate medicine from spirituality and religion and the limitations we often have on recognizing and values traditional knowledge and practices in Western science. In this way, we hope that the results of this study can contribute to the valorization of these ritualistic practices. The industrialized and urban society has benefited from the knowledge of the ancestral people through centuries of exploitation and now is the time to build a new form of relationship with the knowledge of these people, with respect and recognition.

Finally, it is also important to recognize some limitations of this study, such as the small number of Candomblé terreiros, which made it impossible to perform comparative statistical analysis among the three groups. Moreover, since the research dealt with knowledge considered sacred (and often secret) within the cultural and religious context, we assume that some information has not been shared with the researchers. Thus, the data presented in this study comprises only a part, of the broad and complex relationship of these religious groups with plants.

\section{Conclusions}

The Afro-Brazilian religions of the Island of Santa Catarina use a diversity of plants to treat physical and spiritual issues. The plant uses to heal physical symptoms are mainly performed to treat simpler diseases, such as digestive problems, colds, and flu. Concerning liturgical ritual use, in most situations, the direct contact of the plants with the body, as in the case of baths and smoke cleansing, indicates that the active principles of plants may also be having an effect. A group of 16 plants was shared by all the collaborators, demonstrating the importance of these species for the cultural and religious identity of these Afro-Brazilian groups on the Island of Santa Catarina. The presence of these plants in other studies of Afro-Brazilian religions in other parts of Brazil stands out as a characteristic widely shared of these practices, regardless of regional particularities of history and environment. Recognizing the importance and breadth of modern medicine, and even considering the advances in incorporating therapeutic practices that are not only based on drugs, but there is still room for the recognition and appreciation of knowledge and practices of Afro-Brazilian religions, which are constantly undergoing a process of prejudice and discrimination. Thus, we emphasize the importance of recognizing and valuing this ancestral Afro-Brazilian knowledge and learning also from these people about their broader vision of health, combining material and non-material components, which also adds more spirituality in health care.

\section{Acknowledgements \\ We thank all the Babalorixás and Yalorixás who shared their time and knowledge to carry out this research. The unique source of financial resources was through TP master's scholarship from the Coordenação de Aperfeiçoamento de Pessoal de Nível Superior - Brasil (CAPES) - Finance Code 001, through the post-graduation Programme in Fungus, Algae and Plants (Universidade Federal de Santa Catarina). NH thanks to CNPQ for a re- search productivity scholarship (309613/2015-9).}

\section{Authors' contributions \\ Tiago Santos Pagnocca is the leading research for this paper, who collected the data, analyzed, and wrote the text. Natalia Hanazaki participated in the theoretical background, monitoring data collection and analysis, helping with discussions, and wrote the final version of the text. Sofia Zank contributed in the theoretical background, helping with the organization and discussion of the manuscript, and in the writing of the final version of the text. All authors have read and approved the submitted manuscript.}

Funding

No funding was received, except for TP master's scholarship.

Availability of data and materials

The datasets used and/or analyzed during the current study are available from the corresponding author on reasonable request.

Ethics approval and consent to participate

This research was authorized by the Human Research Ethics Committee of the Federal University of Santa Catarina (CEPSH/UFSC) under number 
CAAE47380815.7.0000.0121. The access to traditional knowledge was registered in the Brazilian System of Management of Genetic Resources and Associated Traditional Knowledge (SISGEN) under the number AB01D9.

\section{Consent for publication}

Individual free informed consent was obtained according to the Human Research Ethics Committee of the Federal University of Santa Catarina (CEPSH/UFSC). A copy of the form used is available under request.

\section{Competing interests}

The authors declare that they have no competing interests.

Received: 16 January 2020 Accepted: 14 April 2020

\section{Published online: 25 April 2020}

\section{References}

1. Camargo MTLA. Plantas medicinais e de rituais afro-brasileiros II: estudo etnofarmacobotânico. Editora Ícone: São Paulo; 1998.

2. Voeks RA. Spiritual flora of Brazil's African diaspora: ethnobotanical conversations in the black Atlantic. J Study Religion Nature Culture. 2013. https://doi.org/10.1558/jsrnc.v6i4.501.

3. Albuquerque UP. The use of medicinal plants by the cultural descendants of African people in Brazil. Acta Farm Bon. 2001;20(2):139-44.

4. Albuquerque UP. A little bit of Africa in Brazil: ethnobiology experiences in the field of Afro-Brazilian religions. J Ethnobiology Ethnomedicine. 2014. https://doi.org/10.1186/1746-4269-10-12.

5. Camargo MTLA. As plantas medicinais e o sagrado: a etnofarmacobotânica em uma revisão historiográfica da medicina popular no Brasil. ĺcone: São Paulo; 2014.

6. De Santana BF, Voeks RA, Funch LS. Ethnomedicinal survey of a maroon community in Brazil's Atlantic tropical forest. J. Ethnopharmacol. 2016. https://doi.org/10.1016/j.jep.2016.01.014

7. Ruysschaert S, Andel TV, Putte KV, Damme PV. Bathe the baby to make it strong and healthy: plant use and child care among Saramaccan Maroons in Suriname. J. Ethnopharmacol. 2008, https://doi.org/10.1016/j.jep.2008.10.020.

8. Albuquerque UP, Chiappeta AA. O uso de plantas e a concepção de doença e cura nos cultos afro-brasileiros. Revista Ciência e Trópico. 1994;22: 197-210.

9. Voeks RA. African medicine and magic in Americas. Geographical Review. 1993:83(1):66-78

10. Voeks RA. Sacred leaves of Candomblé: African magic, medicine, and religion in Brazil. Texas: Editora da Universidade do Texas; 1997.

11. Carney JA, Voeks RA. Landscape legacies of the African diáspora in Brazil. Progress in Human Geography. 2003. https://doi.org/10.1191/ 0309132503 ph4180a

12. Fonseca FN, Balick MJ. Plant-knowledge adaptation in an urban setting: Candomblé Ethnobotany in New York City. Economic Botany. 2018. https:// doi.org/10.1007/s12231-018-9405-7.

13. Van Andel TR, Klooster CIEAV, Quiroz D, Towns AM, Ruysschaert S, MVD B. Local plant names reveal that enslaved Africans recognized substantial parts of the New World flora. Proc. Natl. Acad. Sci. U.S.A. 2014. https://doi.org/10. 1073/pnas.1418836111.

14. Paz CE, Lemos ICS, Monteiro AB, Delmondes GA, Fernandes GP, Coutinho HDM, et al. Plantas medicinais no candomblé como elemento de resistência cultural e cuidado à saúde. Rev. Cuba, de Plantas Medicinales. 2015:20:25-37.

15. Serra O, Velozo E, Bandeira F, Pacheco L. O mundo das folhas. Feira de Santana: Universidade Estadual de Feira de Santana; 2002

16. Eltis D. A brief overview of the trans-atlantic slave trade. Voyages: The TransAtlantic Slave Trade Database. 2008.https://www.slavevoyages.org/voyage/ about. Accessed 09 Sep 2019.

17. Verger P. Orixás deuses lorubás na África e no novo mundo. 6ª ed. Corrupio: Salvador; 2002

18. Ribeiro D. O povo brasileiro: a formação e o sentido do Brasil. 2a ed. Companhia das Letras: São Paulo; 1995.

19. Silva VG. Candomblé e Umbanda: caminhos da devoção brasileira. Ática: São Paulo; 1994

20. Lima VC. A Família de Santo nos Candomblés Jêjes-nagôs da Bahia: um estudo de relações intragrupais. Corrupio: Salvador; 2003.

21. Medeiros PM, Soldati GT, Alencar NL, Vandebroek I, Pieroni A, Hanazak $\mathrm{N}$, Albuquerque UP. The use of medicinal plants by migrant people: adaptation, maintenance, and replacement. Evidence-Based
Complementary and Alternative Medicine. 2012. https://doi.org/10.1155/ 2012/807452.

22. Barros JFP. A floresta sagrada de Ossaim: o segredo das folhas. Rio de Janeiro: Pallas; 2014

23. Quiroz D, Sosef M, Van Andel T. Why ritual plant use has ethnopharmacological relevance. J. Ethnopharmacol. 2016. https://doi.org/ 10.1016/j.jep.2016.05.006.

24. Rappaport RA. Ritual and religion in the making of humanity. Cambridge University Press. 1999

25. Prandi R. Referências sociais das religiões afro-brasileiras. Horizontes Antropológicos. 1998;8:151-67. https://doi.org/10.1590/S010471831998000100008

26. Cardoso FH. Negros em Florianópolis: relações sociais e econômicas. Insular: Florianópolis; 2000.

27. Souza DA. A Presença negra no sul do Brasil: reflexões sobre o lugar das questões Afro-brasileiras nas narrativas identitárias de Santa Catarina e nas ações patrimoniais do IPHAN. III Seminário Internacional História do Tempo presente. UDESC, Florianópolis. 2017. http://eventos.udesc.br/ ocs/index.php/STPII/IISIHTP/paper/viewFile/694/439 Accessed 10 Jan 2019

28. Parés LN. A formação do Candomblé: história e ritual da nação jeje na Bahia. 2a ed. Editora da Unicamp: Campinas; 2007.

29. Silva JM. Religiões e Saúde: a experiência da Rede Nacional de Religiões Afro-Brasileiras e Saúde. Saúde e Sociedade. 2007:16:171-7.

30. Saraceni R. Tratado Geral de Umbanda: Compêndios simplificados de Teologia de Umbanda, A Religião dos Mistérios de Deus: As chaves interpretativas. Editora Madras: São Paulo; 2005.

31. Cumino A. Umbanda não é macumba: umbanda é religião e tem fundamento. 2a ed. Madras: São Paulo; 2015.

32. Silva VG. Orixás da metrópole. Vozes: Petrópolis; 1995.

33. Martins G. Ritual de Almas e Angola em Santa Catarina. Florianópolis: ed. do autor; 2006.

34. Saraceni R. A magia divina das sete ervas sagradas. Madras: São Paulo; 2015

35. IPUF -Instituto de planejamento urbano de Florianópolis. Atlas do Município de Florianópolis.2010. https://parquemunicipalmacicodacosteira.files. wordpress.com/2010/05/atlas ipuf.pdf Accessed 10 Jan 2019.

36. Klein RM. Flora ilustrada catarinense: mapa fitogeográfico do Estado de Santa Catarina. Herbário Barbosa Rodrigues, V Parte - mapa fitogeográfico: Itajaí; 1978.

37. IBGE. Instituto Brasileiro de Geografia e Estatística. 2019. http://www.ibge. gov.br. Accessed 10 Jan 2019.

38. Farias DSE, Kneip A. Panorama arqueológico de Santa Catarina. Editora UNISUL: Palhoça; 1992

39. ATLAS. Atlas Escolar de Santa Catarina. Secretaria de Estado de Coordenação Geral e Planejamento. Subsecretaria de Estudos Geográficos e Estatísticos. Rio de Janeiro: Aerofoto Cruzeiro; 1991.

40. Diegues AC, Arruda RSV. Saberes tradicionais e biodiversidade no Brasil. São Paulo: USP; 2001.

41. Piazza WF. Atlas histórico do Estado de Santa Catarina. Florianópolis: Secretaria da Educação e Cultura. 1970

42. Piazza WF. A escravidão negra numa província periférica. Garapuvu: Florianópolis; 1999.

43. Piazza WF. A colonização de Santa Catarina. Florianópolis: Editora Lunardelli. 1994.

44. Tramonte C Com a bandeira de Oxalá: trajetórias, práticas e concepções das religiões afro-brasileiras na Grande Florianópolis. Itajaí: UNIVALI; 2001.

45. UNIAFRO - União de Cultura Negra em Santa Catarina.2019. http://www. uniafro.xpg.com.br Accessed 10 Jan 2019.

46. Bernard HR. Research methods in anthropology: qualitative and quantitative approaches: Altamira Press; 2006

47. Alexiades MN. Protocol for conducting ethnobotanical research in the tropics. In: Alexiades MN, editor. Selected Guidelines for Ethnobotanical Research: A Field Manual. The New York Botanical Garden Press: New York; 1996. p. 5-18.

48. Rotta E, Beltrami LCC, Zonta M. Manual de prática de coleta e herborização de material botânico. Embrapa Florestas: Colombo; 2008

49. The Plant List. Version 1.1. 2013. http://www.theplantlist.org/ Accessed 1st Jan 2019

50. Coradin L, Siminski A, Reis A. Espécies nativas da flora brasileira de valor econômico atual ou potencial: plantas para o futuro - Região Sul. Brasília: MMA; 2011. 
51. Joly $A B$. Botânica: introdução a taxonomia vegetal. Editora Nacional: São Paulo; 1991.

52. Lorenzi H, Matos FJA. Plantas medicinais no Brasil - Nativas e Exóticas. Instituto Plantarum: Nova Odessa; 2008.

53. Lorenzi H, Souza HM. Plantas ornamentais no Brasil (arbustivas herbáceas e trepadeiras). Instituto Plantarum: Nova Odessa; 2008.

54. ICPC. International classification of primary care. 2019. http://www.who.int/ classifications/icd/adaptations/icpc2/en/ Accessed 09Sep 2019.

55. Weckerle CS, de Boer HJ, Puri RK, van Andel T, Bussmann RW, Leonti M. Recommended standards for conducting and reporting ethnopharmacological field studies. J.Ethnopharmacol. 2018. https://doi.org/ 10.1016/j.jep.2017.08.018.

56. Vavilov NI. Origin and geography of cultivated plants. Cambridge: Cambridge University Press; 1992.

57. Prance G, Nesbitt M. The cultural history of plants. New York: Routledge; 2005

58. Flora do Brasil. Jardim Botânico do Rio de Janeiro.2019. http://floradobrasil. jbrj.gov.br/ Accessed 09 Sep 2019

59. Alves KCH, Povh JA, Portuguez AP. Etnobotância de plantas ritualísticas na prática religiosa de matriz africana em Ituiutaba, Minas Gerais, Brasil. Ethnoscientia. 2019; doi: 10.22276/ethnoscientia.v4i1.239.

60. Voeks RA. Sacred leaves of Brazilian Candomblé. Geographical Review. 1990; 80(2):118-31.

61. Carvalho PA, Barros VMS, Zonta PL, Souza HN. Manutenção da tradição e do conhecimento sobre plantas medicinais em terreiros de Umbanda e Candomblé na Zona da Mata de Minas Gerais. Cadernos de Agroecologia. 2015;10:3.

62. TorresVS. Relação de espécies botânicas empregadas nos templos de Umbanda Nagô. UNISANTA Bioscience. 2018; 7(2): 153-190.

63. Gomes HHS, Dantas IC, Catão MHC. Plantas medicinais: sua utilização em terreiros de umbanda e candomblé na zona leste da cidade de Campina Grande-PB. Revista de Biologia e Farmácia. 2008;3.

64. Pires MV, Abreu PP, Soares CS, Silva DC, Souza BN, Mariano DM, et al. Etnobotânica de Terreiros de Candomblé nos Municípios de Ilhéus e Itabuna, Bahia. Brasil. Revista Brasileira de Biociencias. 2009;7:3-8.

65. Mercês Júnior JG. Os encantos de Òsùn: o àse de suas ervas usadas no candomblé Kétu-Nàgó. (Professional Master) Postgraduate Program in Religious Sciences. United Faculty of Victoria; 2018

66. Ferreira, M.E.A., 2017. Plantas medicinais utilizadas em rituais de religiões de matriz afro-brasileira: estudo de caso umbanda. (Monography) Biological Sciences Undergraduate Course, University of the extreme south of Santa Catarina (UNESC).44p.

67. Garcia D, Medeiros TA, Ribeiro C, Santos JFL, Neto J.S.Antonio RL, et al. Defumadores com possível efeito ansiolítico utilizados no centro de umbanda caboclo ubirajara e exú ventania, diadema, SP: um estudo etnofarmacológico. Ethnoscientia. 2016;doi: https://doi.org/10.22276/ ethnoscientia.v1i1.16.

68. Araujo W. Através da terra: estudo etnobotânico de plantas utilizadas em rituais de cura por participantes de cultos religiosos de Matriz Africana em Campina Grande-PB. (Monography) Nursing Undergraduate Course, State University of Paraíba; 2014.

69. Gomes AMS. Rotas e diálogos de saberes da etnobotânica transatlântica negroafricana. (Doctoral Thesis) Postgraduate in Geography, Federal University of Minas Gerais:2009.

70. Cruz LM, Hanazaki N. The ethnobotany of an Afro-Brazilian community at Sertão do Valongo, Santa Catarina. Brazil. Functional Ecosystems and Communities. 2008;2:59-65.

71. Silva NCB, Regis ACD, Almeida MZ. Estudo Etnobotânico em Comunidades Remanescentes de Quilombo em Rio de Contas - Chapada Diamantina Bahia. Revista Fitos. 2013;7(2):99-109.

72. Zank S, Avila JVC, Hanazaki N. Compreendendo a relação entre saúde do ambiente e saúde humana em comunidades Quilombolas de Santa Catarina. Revista brasileira de plantas medicinais. 2016. https://doi.org/10. 1590/1983-084X/15 142

73. Albuquerque UP, Andrade LHC. Etnobotánica del gênero Ocimum L. (Lamiaceae) en las comunidades afrobrasileñas. Anales Jard. Bot. Madrid. 1998:56:107-18.

74. Braga AP, de Sousa Fl, da Silva Junior GB, Nations MK, Barros ARC, Amorim RF. Perception of Candomble practitioners about herbal medicine and health promotion in Ceará. Brazil. J Relig Health. 2018. https://doi.org/10. 1007/s10943-017-0441-x
75. Rodrigues E, Carlini ELA. Levantamento etnofarmacológico realizado entre um grupo de quilombolas do Brasil. Arq. bras. fitomed. cientif. 2003;1(2):80-7.

76. Gomes TB, Bandeira FPSF. Uso e diversidade de plantas medicinais em uma comunidade quilombola no Raso da Catarina. Bahia. Acta Bot. Bras. 2012. https://doi.org/10.1590/S0102-33062012000400009.

77. Klooster CIEA, Haabo V, Ruysschaert S, Vossen T, van Andel TR. Herbal bathing: an analysis of variation in plant use among Saramaccan and Aucan Maroons in Suriname. J Ethnob Ethnom. 2018. https://doi.org/10.1186/ s13002-018-0216-9.

78. Vossen T, Towns A, Ruysschaert S, Quiroz D, Van Andel T. Consequences of the trans-Atlantic slave trade on medicinal plant selection: plant use for cultural bound syndromes affecting children in Suriname and Western Africa. PLoS ONE. 2014. https://doi.org/10.1371/journal.pone.0112345.

79. Albuquerque UP, Monteiro JM, Ramos MA, de Amorim EL. Medicinal and magic plants from a public market in northeastern Brazil. J Ethnopharmacol. 2007. https://doi.org/10.1016/j.jep.2006.09.010.

80. Zank S, Hanazaki N. The coexistence of traditional medicine and biomedicine: a study with local health experts in two Brazilian regions. PLoS ONE. 2017. https://doi.org/10.1371/journal.pone.0174731.

81. Van Andel TR, Ruysschaert S, Putte KV. What makes a plant magic? Symbolism and Sacred Herbs in Afro-Surinamese Rituals.In: Voeks R, Rashford J, editors. African Ethnobotany in the Americas (New York: Springer); 2013. p. 247-284

82. Ayob Z, Bohari SPM, Samad AA, Jamil S 2014. Cytotoxic activities against breast cancer cells of local Justicia gendarussa crude extracts. Evid Based Complement Alternat Med . 2014; doi: https://doi.org/10.1155/2014/732980.

83. Pal K, Rahaman CH. Phytochemical and antioxidant studies of Justicia gendarussa Burm.F. an ethnomedicinal plant. Int. J. Pharm. Sci. 2015;6:3454-62.

84. Andhare RN, Raut MK, Naik SR. Evaluation of antiallergic and antianaphylactic activity of ethanolic extract of Sansevieria trifasciata leaves (EEST) in rodents. J. Ethnopharmacol. 2012. https://doi.org/10.1016/j.jep. 2012.05.007.

85. Dey B, Bhattacharjee R, Mitra A, Singla RK, Pal A. Mechanistic explorations of antidiabetic potentials Sansevieria trifasciata. Indo glob. j. pharm. 2014;4: 113-22.

86. Kageyama A, Ueno T, Oshio M, Masuda $H$, Horiuchi $H$, Yogoshi $H$. Antidepressant- like effects of an aqueous extract of lavender (lavandula angustifolia Mill.) in rats. Food Sci Technol Res. 2012; doi: 10.3136/fstr.18.473.

87. Algieri F, Nogales AR, Vezza T, Mesa JG, Mesa NG, Utrilla MP, et al. Antiinflammatory activity of hydroalcoholic extracts of Lavandula dentata L. e Lavandula stoechas L. J. Ethnopharmacol.2016; doi: https://doi.org/10.1016/j. jep.2016.05.063.

88. Orlanda JFF, Nascimento AR. Chemical composition and antibacterial activity of Ruta graveolens L. (Rutaceae) volatile oils, from São Luís, Maranhão, Brazil. South African Journal of Botany. 2015; doi: https://doi.org/ 10.1016/j.sajb.2015.03.198.

89. Alves TC, Rodrigues E, Lago JHG, Prado CM, Girardi CEN, Hipólide DC. Petiveria alliacea, a plant used in Afro-Brazilian smoke rituals, triggerspulmonary inflammation in rats. Rev. bras. farmacogn. 2019. https:// doi.org/10.1016/j.bjp.2019.06.005

90. Matory JL. Black Atlantic religion: tradition, transnationalism, and matriarchy in the Afro-Brazilian Candomblé: Pinceton University Press; 2005.

91. Voeks RA, Rashford J. African ethnobotany in the Americas. New York: Springer; 2013.

92. Barnes BA, Fox LE. Poisoning with dieffenbachia. J History Med Allied Sci. 1955;10:173-81.

93. Reyes-García $\vee$. The relevance of traditional knowledge systems for ethno pharmacological research: theoretical and methodological contributions. J. Ethnobiol. Ethnomed. 2010. https://doi.org/10.1186/1746-4269-6-32.

\section{Publisher's Note}

Springer Nature remains neutral with regard to jurisdictional claims in published maps and institutional affiliations. 